\title{
Sacrilisation of secular pilgrimages as archetypal transformational journeys: advancing theory through emic and etic interpretations
}

\author{
Stephen Lloyd \\ Business School, \\ AUT University, \\ Private Bag 92006, Auckland 1142, \\ New Zealand \\ Email: Stephen.Lloyd@aut.ac.nz
}

\begin{abstract}
This paper advances pilgrimage tourism theory, particularly religious/secular and sacred/profane dimensions. Documenting the case of the Bach Cantata Pilgrimage, this study examines relationships to Jungian archetypal journeys. Case analysis of the Pilgrimage employs emic and etic interpretation. Results suggest that the experience has sacred dimensions when pilgrimage activities align with participants' core values. The study identifies spiritual dimensions of secular pilgrimage as expressions of an archetypal journey, and points to opportunities to communicate the pilgrimage experience's authenticity, virtually, through digital communications. A further contribution is demonstrating the usefulness of emic and etic interpretations in identifying motivations to participate in secular pilgrimage.
\end{abstract}

Keywords: pilgrimage tourism; archetypal journey; sacralisation; tourism anthropology.

Reference to this paper should be made as follows: Lloyd, S. (2015) 'Sacrilisation of secular pilgrimages as archetypal transformational journeys: advancing theory through emic and etic interpretations', Int. J. Tourism Anthropology, Vol. 4, No. 1, pp.25-45.

Biographical notes: Stephen Lloyd is a Senior Lecturer with the AUT Business School and completed his PhD on 'Corporate reputation: ontology and measurement'. His areas of research interest include marketing communications and advertising effectiveness, brand strategy and symbolism. He has helped some of the world's most famous brands build value properties across cultures and across a range of highly competitive categories. His assignments have included Nestle, Kraft, Kellogg's, Coca-Cola, Gillette, Johnson \& Johnson and L'Oreal.

\section{Introduction}

The study of pilgrimage is a continuing interest for researchers in tourism, anthropology and sociology (Badone and Roseman, 2004; Cohen, 1992; Collins-Kreiner, 2010; Eade, 1992; Eade and Sallnow, 2000; Reader and Walter, 1992). Pilgrimages are enactments of sacred journeys and are viewable as either religious and based on a sense of obligation (Bridger et al., 1976; Houtsma et al., 1993; Yang, 1961), devotion (Turner and Turner, 1978), or secular and more likely to be voluntaristic. 
This study examines how the sacred and profane dichotomy informs some explanations of pilgrimages (Eliade, 1959). Some pilgrimages are secular journeys, a rite de passage or pathway to identity, meaning or self-realisation (Digance, 2006; Hyde and Harman, 2011). While secular pilgrimages may lack religious motivation and legitimation, they arguably may include a sacred dimension. The paper here explores how a secular pilgrimage can be a journey inspired by a sacred dimension and which involves a spiritual experience and enables a high level of social, personal and spiritual engagement.

This study examines the case of the "Bach Cantata Pilgrimage of 2000" (hereafter, the 'Pilgrimage') and the possibility that the Pilgrimage may represent a new form of secular pilgrimage: 'sacralisation' is a means for transforming a secular pilgrimage that is not initiated by an adherence to established religious doctrine yet has a sacred dimension or story that can inspire this pilgrimage form. The Pilgrimage evokes a spiritual experience among participants; digital communications technology enables a high level of engagement (Hunt and Menon, 1995) with Bach's music, with sites, and with a pilgrimage experience.

The Monteverdi Choir, the English Baroque Soloists, and their director Sir John Eliot Gardiner (JEG) embarked on the Pilgrimage with a performance of the Christmas Oratorio in Weimar on Christmas Day 1999. The first of the sacred cantatas was performed in Berlin on January 1, 2000. The cantata is a musical composition for voices and orchestra based on a religious text (Princeton University Cognitive Science Lab, 2005) and is performed on days relating to liturgy, a Christian sacrament commemorating the Last Supper. The Pilgrimage was without precedent and a unique celebration of the new millennium and of the 250th anniversary of Johann Sebastian Bach's (JSB) death. The Pilgrimage's goal was to perform all JSB's surviving church cantatas on the liturgical days for which they were composed, in a year-long musical pilgrimage. JEG describes the challenge:
"With weekly preparations leading to the performances of these extraordinary works, a working rhythm we sustained throughout a whole year, our approach was influenced by several factors: time (never enough), geography (the initial retracing of Bach's footsteps in Thuringia and Saxony), architecture (the churches both great and small where we performed), the impact of one week's music on the next ... and inevitably, the hazards of weather, travel and fatigue." (Gardiner, 2011)

The Pilgrimage visited some of the most beautiful churches in Europe, including many where JSB performed, and culminated in three concerts in New York City over the Christmas holidays and at the end of the millennium. Recordings were made of performances throughout the pilgrimage. Table 1 includes the churches pilgrims visited and performed in.

Information technology advancements open new channels of communication (Schultz, 2003a) and new opportunities to extend the pilgrimage experience beyond individuals physically participating in a pilgrimage. While the literature addresses developments and benefits of digital communications (Hulten, 2011), further research is required to document their value to a secular pilgrimage in extending the pilgrimage experience among pilgrims. To achieve this objective, the study here examines the contribution of the literature on sacred and secular pilgrimage to an understanding of a specific case: the Pilgrimage project. 
Sacrilisation of secular pilgrimages as archetypal transformational journeys 27

Table 1 Bach pilgrimage performance destinations (January-December 2000)

\begin{tabular}{|c|c|}
\hline Performance destination & Date (2000) \\
\hline Gethsemanekirche, Berlin & 1 January \\
\hline Herderkirche, Weimar & 26 December \\
\hline Nicholaikirche, Leipzig & 6 January \\
\hline Hauptkirche St Jacobi, Hamburg & 9 January \\
\hline Old Royal Naval College, Greenwich, London & 16-17 January \\
\hline Romsey Abbey, Hampshire & 30 January \\
\hline Grote Kerk, Naarden & 20 February \\
\hline Southwell Minster & 27 February \\
\hline King's College Chapel, Cambridge & 5 March \\
\hline Walpole St Peter, Norfolk & 26 March \\
\hline Georgenkirche, Eisenach & 23-25 April \\
\hline Johann-Sebastian-Bach-Kirche, Arnstadt & 29-30 April \\
\hline Basilique St Willibrord, Echternach & 7 May \\
\hline Schlosskirche, Altenburg & 14 May \\
\hline St Mary's, Warwick & 21 May \\
\hline Annenkirche, Dresden & 27-28 May \\
\hline Sherborne Abbey & 4 June \\
\hline Holy Trinity, Long Melford & 11-12 June \\
\hline Holy Trinity, Blythburgh & 13 June \\
\hline St. Magnus Cathedral, Kirkwall & 18 June \\
\hline St. Giles Cripplegate, London & $23-24 ; 25-26$ June \\
\hline Basilique Saint-Denis, Paris & 2-3 July \\
\hline Fraumünster, Zürich & 8-9 July \\
\hline Tewkesbury Abbey & 16 July \\
\hline Blasiuskirche, Mülhausen & 23 July \\
\hline St Gumbertus, Ansbach & 30 July \\
\hline St Marys, Haddington & 5-6 August \\
\hline Christkirche, Rendsburg & 13 August \\
\hline Dom, Braunschweig & 27 August \\
\hline St. David's Cathedral, Wales & 3 September \\
\hline Jakobskirche, Köthen & 10 September \\
\hline Dreikönigskirche, Frankfurt & 17 September \\
\hline Abbaye d'Abronay & 24 September \\
\hline Unser Leiben Frauen, Bremen & 28-29 September \\
\hline Santo Domingo de Bonoval, Santiago de Compostela & 7 October \\
\hline Alhelgonakyrkan, Lund & 14 October \\
\hline Thomaskirche, Leipzig & 22 October \\
\hline
\end{tabular}


Table 1 Bach pilgrimage performance destinations (January-December 2000) (continued)

\begin{tabular}{lc}
\hline Performance destination & Date (2000) \\
\hline Erlöserkirche, Potsdam & 29 October \\
Schlosskirche, Wittenberg & 31 October \\
Cattedrale de San Lorenzo, Genoa & 4 November \\
Old Royal Naval College Chapel, Greenwich & $11-12$ November \\
All Saints Tooting, London & 17 November \\
Winchester Cathedral & 26 November \\
St Maria im Kapitol, Köln & 3 December \\
Michaeliskirche, Lüneburg & 10 December \\
St Bartholomew's, New York & 25,27, and 31 December \\
\hline
\end{tabular}

This study examines the Pilgrimage planning, strategy, and implementation and how a loose-coupling of organisations and individuals serve to communicate the Pilgrimage story; a story whose imagery, affect and attentional focus may transport individuals into a different reality (Green and Brock, 2000) while maintaining the integrity, authenticity and values of a sacred journey.

\section{The dimensions of secular pilgrimage}

\subsection{Secular pilgrimage}

The secularisation of society suggests that the "rigid dichotomies between pilgrimage and tourism, or pilgrims and tourists, no longer seem tenable in the shifting world of postmodern travel" [Badone and Roseman, (2004), p.2]. This paper's challenge is to make sense (Weick et al., 2005) of what a group of musical performers themselves call a pilgrimage. The project is officially sanctioned and involves travelling to places of significance to the sacred music of JSB. One stage includes a visit to Bach's grave and a performance in the church which contains his grave. The Pilgrimage's geographic and virtual dimensions engage the interest and participation of those who may share some of the characteristics of the purposeful cultural tourist (McKercher and du Cros, 2002). The paper here hopes to build on the concept of virtual pilgrimage (Guttentag, 2010).

The site has a socio-psychological significance as a medium through which specific needs can be satisfied (Hyde and Harman, 2011). This idea informs consideration of pilgrimage as travel to, and communion with, a site that embodies and makes manifest the religious, cultural or personal values of the individual; the deeply meaningful, or a source of core identity for the traveller (Digance, 2006; Hyde and Harman, 2011). Yet a pilgrimage may incorporate multiple sites. A pilgrimage ultimately to the shrine of Saint James of Compostella would include visits to and worship at various pilgrimage sites along the route, for example at Capildo Cathedral, Pampelona; the Monasterio de Irachi; the Cathedral Santa Maria de la Redondra, Lograno; and the Iglesia del Santo Sepulcro, at Torres de Rio in Navarra.

The popularisation of pilgrimage (Reader and Walter, 1992) opens up the possibility for expanding the nature and function of pilgrimage in a secularised society. In a secularised society pilgrimage may provide functional alternatives (Martin, 1978) to 
religious pilgrimage. Alternatively, pilgrimage in a secularised society may provide a surrogate (Wilson, 1966) for traditional pilgrimage religiosity. In what ways can a visit to the Thiepval Arch (Aslet, 2012) and to Graceland (Alderman, 2002) be called a pilgrimage? Does pilgrimage need to be legitimised by a religious organisation or sanctioned socially?

\subsection{The sacred and profane dichotomy}

The domain of the sacred, as distinct from the profane, is important to pilgrimage, tourism, and to marketing theory and practice (Belk et al., 1989). Considerations of the sacred, the profane and the secular inform the work of Smith (1992) which attests to a broad definition of the term pilgrim and pilgrimage. The term pilgrimage connotes a religious journey; a tourist on the other hand embarks on a vacation-orientated journey for pleasure. A theoretical issue that Smith's (1992) interpretation raises is an assumption that a secular orientation implies necessarily an orientation towards the profane. " ... While the designations are by no means immutable. Between the extremities lie almost infinite possible sacred-secular combinations ..." [Smith, (1992), p.4]. This statement suggests the possibility of forms of secular sacrality (Bellah, 1980; Berger, 1967; Martin, 1978; Wilson, 1966) that may in certain cases (e.g., the subject of this study) rid certain secular pilgrimages of the profane.

This view follows the Durkheimian notion of the sacred and the profane (Durkheim, 2008). "For us sacred things and places are to be protected from defilement" [Douglas, (1966), p.7]. Holiness and impurity are at opposite poles (Douglas, 1966). For Eliade (1959), the idea of sanctity may have become very specialised - possibly as religion has become more institutionalised (Weber, 1964). In some primitive cultures, the sacred may mean little more than a prohibition (Eliade, 1996). The question "what is the sacred" is still asked (Scruton, 2014). Scruton (2014, p.11) suggests that: "To those who respect them ... sacred things are the real presence of the supernatural, illuminated by a light that shines from the edge of the world".

The religious/secular aligns with the sacred/profane dimensions as a forced and contradictory fit. In this case, sacred and profane are more akin to the value orientation than to the institutional nature of the pilgrimage. The value orientation of Chaucer's pilgrim, the Pardoner (Pearsall, 1983) would, by today's values, be considered profane and in bad faith.

The present study suggests that the sacred and the profane are classifications (Durkheim and Mauss, 1967); religious and secular are social responses (Bellah, 1964; Wilson, 1999). Indeed the religious and the secular, like rationality and disenchantment, connect intimately (Gellner, 1974). The religious in a legal rational-society becomes secular and develops alternative (e.g., scientific, environmental) sources of legitimation (Yearley, 1992).

\subsection{The study of pilgrimage tourism}

Cohen (1992) differentiates between formal and popular pilgrimage. During a time of great social change, new touristic fairs and festivals begin to emerge at traditional religious pilgrimage sites. Such changes prompt a return to an earlier consideration of differences between pilgrims and tourists (Cohen, 1991) whereby pilgrims are travellers returning to the socio-cultural centres of their society, and tourists are travellers going 
away from their centres and toward the periphery. Formal and popular pilgrimage need not be mutually exclusive. Developing the concept of the secular pilgrimage may bridge this dichotomy.

There is evidence of a change in approach to the study of pilgrimage, with regard to the intermingling of the concepts of tourism and pilgrimage; pilgrimage, especially in an age of digital communication, is no longer seen as a form of population mobility (Collins-Kreiner, 2010). The term religious tourism has been adopted (Olsen, 2010). This is especially true given the adoption of the differentiation between secular and religious pilgrimage. The present study examines the Pilgrimage as a sacred journey and considers the journey as a form of individuation, or self-realisation; a response to the powerful influence of archetypes of deeply held myths throughout the journey towards individuation (Jung, 1940, 1968).

\subsection{Cultural orientation}

A challenge for the study of culture is to understand habits of thought and emotion and the patterns into which these habits fall (Benedict, 1946). This process can involve exploring the "rules and values of [the] culture ... with people who had actually lived it" [Benedict, (1946), p.6]. Such is the orientation of the present study which seeks to understand the meaning of pilgrimage for those people who engage in the activity.

Cultural factors influence responses to situations (Hofstede, 2003; Weber, 1930). Cultural values shape and justify individual and group beliefs, actions and goals. The cultural values of interest in this paper are those that influence the degree of sacrality in the pilgrimage. Values serve as standards or criteria; the relative importance of values guides action (Schwartz, 2006). Cultural values impact upon the phenomenon of the pilgrimage in that the pilgrimage is shaped by cultural values. Based on this theoretical orientation, this paper proposes that the Pilgrimage represents a culture of shared values with a shared orientation towards the sacred.

The pilgrim-tourist path suggests, "When viewed in a temporal context juxtaposed with its philosophical counterparts of faith and knowledge, pilgrimage is by no means a simple one-lane track" [Smith, (1992), p.13].

\subsection{Archetypes}

The psychology literature attests to the validity of a theoretical foundation for the study of unconscious thinking's influence on behaviour (Woodside, 2008). Jung (1968) identifies a type of unconscious process which is not directly observable, is of unknown origin and of mythological character and constitutes a pattern peculiar to mankind in general: this Jung calls the collective unconscious (Jung, 1968). The patterns of the collective unconscious Jung calls archetypes.

Archetypes are universal and elemental mental forms; their images attract, convince, and overpower (Jung, 1940). Any activated archetype can appear in projection and by transference, "into an external situation or into people, or into circumstances - in short, into all sorts of objects" [Jung, (1968), p.158]. Analysing the Pilgrimage as an archetypal journey the paper here contributes to understanding motivations to participate in a secular pilgrimage as an experiential process of individuation of the self (Jung, 1969). 


\subsection{Individuation}

Consideration of the theory of individuation (Jung, 1940, 1968) provides insight into how people make sense of archetypes in everyday experiences. If the creative artist, such as JSB and each of those participating in the Pilgrimage, is spawned by archetypal forces (Jung, 1966) which impel the creative work into existence, so too may the various types of pilgrim hope to participate, directly, vicariously, in their own ways, in the activation of the archetype. Jung's concept of individuation (Jung, 1940) informs the motivation to engage in the Pilgrimage.

Specifically, the Pilgrimage is an expression of the archetypal journey that satisfies the powerful need for identification, by the pilgrim, with the totality of the personality; with the self. For some participants this journey serves as a psychological and a spiritual healing process (Jung, 1968) quite distinct from the bodily healing role of pilgrimage (Dahlberg, 1991). The process of individuation (Jung, 1940) may be similar to the process of self-realisation that Hyde and Harman (2011) describe.

The present study includes the following research objectives (RO).

$\mathrm{RO}_{1}$ identify the intentions and other characteristics of the communications

$\mathrm{RO}_{2}$ explore the psychological state of pilgrims

$\mathrm{RO}_{3}$ reveal the focus of individual and group attention

$\mathrm{RO}_{4}$ explore the relevance of archetypes for identifying the motivation to participate in a pilgrimage.

\section{Exploring and interpreting the meaning of the pilgrimage}

This study assumes that the Pilgrimage is a cultural expression shaped by a variety of orientations towards the spiritual. The domain of the sacred, as distinct from the profane, is important to tourism theory and practice (Belk et al., 1989). A Weberian methodology is adopted in the study of pilgrimage tourism (Olsen, 2010). An interpretive anthropology, inspired by interpretive sociology (Weber, 1978), attempts to understand the sacred within a broad cultural and symbolic domain. Such an approach incorporates thick description (Geertz, 1973) based on an (etic) interpretation of people's own (emic) interpretations, or stories, of events and based on the anthropologist's empirical knowledge.

The approach may approximate to a phenomenology that looks at essential structures and meanings as Eliade (1963a) exemplifies. This may be a sacred space discovered rather than created by man and which "in some way or other reveals itself to him" [Eliade, (1963a), p.371]. This orientation incorporates religious symbolism and the structural study of sacred time, space, and history. The orientation has relevance for a study of the Pilgrimage in that participants own emic descriptions of their experience have the potential to provide a rich source of insight into the meaning of pilgrimage for participants and into their definitions of the situation and their construction of sacred space. Study results become propositions that are open to empirical validation. 


\subsection{Material and experiences reviewed}

The personal experiences of the musicians and singers involved in the Pilgrimage provide the primary data for the study. Data for the study also include items recorded and published between 2000-2011 about the Pilgrimage, with the exception of live performances of which the researchers analysed video and sound recordings. Table 2 shows the data sources which include a launch event and subsequent public relations (PR) and publicity; the Pilgrimage internet site and blogs; digital recordings: CDs of all concerts at Pilgrimage sites and a DVD of concerts and interviews with Pilgrims; promotional e-mailings from http://www.solideogloria.co.uk which provides details of new releases and insights into the Pilgrimage progress. The study here includes an analysis of all of these materials.

The personal experiences of Pilgrims appear in words and personal photographs taken along the route and reproduced in e-mails, blogs and the illustrated notes that accompany Pilgrimage concert recordings. Throughout the Pilgrimage, and the release of $\mathrm{CD}$ and DVD recordings (and the ensuing publicity and awards), the researchers were virtual pilgrimage participants, viewers of all DVD and listeners of all CD recordings; readers of all $\mathrm{CD}$, e-mail and internet communications.

Historical content analysis (HCA) is used because the method satisfies the need for rigor and sensitivity. HCA uses a set of procedures and makes valid inferences based on an analysis of text (Weber, 1990) - requiring a systematic, objective identification of specified characteristics within the text (Stone et al., 1966). The method analyses written and recorded material into meaningful units, using carefully applied rules. HCA is conducted on data in Table 2.

Table 2 Bach pilgrimage data sources (January-July 2011)

\begin{tabular}{|c|c|c|c|}
\hline Location & Content & Medium & Date (2000) \\
\hline \multirow[t]{2}{*}{ London } & Launch event & DVD & 1999 \\
\hline & JEG interview & & \\
\hline Herderkirche, Weimar & Concert & $\begin{array}{c}\mathrm{CD}, \mathrm{CD} \\
\text { commentary, DVD }\end{array}$ & 26 December \\
\hline $\begin{array}{l}\text { Hauptkirche St Jacobi, } \\
\text { Hamburg }\end{array}$ & Concert & $\begin{array}{c}\mathrm{CD}, \mathrm{CD} \\
\text { commentary, DVD }\end{array}$ & 9 January \\
\hline Southwell Minster & Concert & $\begin{array}{c}\mathrm{CD}, \mathrm{CD} \\
\text { commentary, DVD }\end{array}$ & 27 February \\
\hline Georgenkirche, Eisenach & Concert & $\begin{array}{c}\mathrm{CD}, \mathrm{CD} \\
\text { commentary, DVD }\end{array}$ & 23-25 April \\
\hline $\begin{array}{l}\text { Johann-Sebastian-Bach-Kirche, } \\
\text { Arnstadt }\end{array}$ & Concert & $\begin{array}{c}\mathrm{CD}, \mathrm{CD} \\
\text { commentary, DVD }\end{array}$ & 29 and 30 April \\
\hline $\begin{array}{l}\text { Basilique St Willibrord, } \\
\text { Echternach }\end{array}$ & Concert & $\begin{array}{c}\mathrm{CD}, \mathrm{CD} \\
\text { commentary, DVD }\end{array}$ & 7 May \\
\hline Holy Trinity, Long Melford & Concert & $\begin{array}{c}\mathrm{CD}, \mathrm{CD} \\
\text { commentary, DVD }\end{array}$ & 11 and 12 June \\
\hline Holy Trinity, Blythburgh & Concert & $\begin{array}{c}\mathrm{CD}, \mathrm{CD} \\
\text { commentary, DVD }\end{array}$ & 13 June \\
\hline
\end{tabular}


Sacrilisation of secular pilgrimages as archetypal transformational journeys 33

Table 2 Bach pilgrimage data sources (January-July 2011) (continued)

\begin{tabular}{|c|c|c|c|}
\hline Location & Content & Medium & Date (2000) \\
\hline St Magnus Cathedral, Kirkwall & Concert, JEG interview & $\begin{array}{c}\mathrm{CD}, \mathrm{CD} \\
\text { commentary, DVD }\end{array}$ & 18 June \\
\hline Iona Abbey & JEG interview & DVD & June \\
\hline Blasiuskirche, Mülhausen & Concert & $\begin{array}{c}\mathrm{CD}, \mathrm{CD} \\
\text { commentary, DVD }\end{array}$ & 23 July \\
\hline St David's Cathedral, Wales & Concert & $\begin{array}{c}\mathrm{CD}, \mathrm{CD} \\
\text { commentary, DVD }\end{array}$ & 3 September \\
\hline Thomaskirche, Leipzig & Concert & $\begin{array}{c}\text { CD, CD } \\
\text { commentary, DVD }\end{array}$ & 22 October \\
\hline Train journey & $\begin{array}{l}\text { Nicholas Robertson, } \\
\text { Marcel Buceele, Kati } \\
\text { Debretseni, Susan } \\
\text { Flowers interviews }\end{array}$ & DVD & October 2000 \\
\hline Michaeliskirche, Lüneburg & Concert, JEG interview & $\begin{array}{c}\mathrm{CD}, \mathrm{CD} \\
\text { commentary, DVD }\end{array}$ & 10 December \\
\hline St Bartholomew's, New York & $\begin{array}{l}\text { Concert, JEG, Martin } \\
\text { Truscott, Kati } \\
\text { Debretsini interviews }\end{array}$ & $\begin{array}{c}\mathrm{CD}, \mathrm{CD} \\
\text { commentary, DVD }\end{array}$ & $\begin{array}{c}25,27 \text { and } 31 \\
\text { December }\end{array}$ \\
\hline $\begin{array}{l}\text { Journal of JEG written in the } \\
\text { course of the Bach Cantata } \\
\text { Pilgrimage }\end{array}$ & Diary & Website & 2004 \\
\hline E-mails & $\begin{array}{l}\text { Information on } \\
\text { Pilgrimage experiences } \\
\text { and new releases }\end{array}$ & $\begin{array}{l}\text { HTML graphic } \\
\text { files }\end{array}$ & 2003-2011 \\
\hline $\begin{array}{l}\text { Bach Cantatas Gardiner } \\
\text { Volumes } 1-27\end{array}$ & $\begin{array}{l}\text { Concert recordings and } \\
\text { notes on concerts and } \\
\text { the music }\end{array}$ & $\begin{array}{l}\text { CD copy and } \\
\text { visuals }\end{array}$ & 2005-2010 \\
\hline Publicity & Reviews and awards & $\begin{array}{l}\text { E-mails, websites } \\
\text { and blogs }\end{array}$ & 2006-2011 \\
\hline
\end{tabular}

This study uses an interpretive rather than a computer-based mode of content analysis. For this reason the comparability of results may be limited. Rather than employing a systematic coding procedure, this paper relies on the researchers' etic interpretation based on their empirical knowledge.

\subsection{Visual narrative art}

The researchers' analytical interpretation is extended through the use of visual narrative art (VNA). VNA in the context of the Pilgrimage is the use of researcher-created visualisations of stories relating to text and non-text materials in order to diagnose conscious and unconscious meanings of the Pilgrimage. Whereas VNA offers the protagonists an opportunity for self-reflection, the present study uses VNA as a diagnostic tool by the researcher. Megehee and Woodside (2010) suggest that VNA 
revises and deepens understanding of an event's meaning in the story, and of what the complete story implies about the relationship between a participant (pilgrim) and the activity (Pilgrimage). Pilgrims' own stories of their feelings and experiences surface unconscious thinking in relation to the Pilgrimage experience, and how this thinking reflects one or more archetype fulfilments (Megehee and Woodside, 2010) by the pilgrim/storyteller. Pilgrims' narrative accounts serve to inform etic interpretation of their self-reports.

The approach to applying VNA in this paper is consistent with Megehee and Woodside (2010). VNA uses pattern recognition to identify common components of the Pilgrimage and of the experiential processes that comprise individuation (Jung, 1969). This study follows phase dynamics theory (PDT) for analysing secular pilgrims' selfnarratives (Woodside and Megehee, 2009).

Woodside and Megehee (2009) indicate five stages of PDT for epiphany travel, or phases in the protagonist's cognitive and emotional preparedness to more fully answer the question, "Who am I?" Triggers, or motivating states and experiences, provide segues between phases in preparing to start a story (prequel and awakening); in engaging in the story's action (journey and catharsis); and later in re-experiencing (post-journey storytelling and [re]interpretations) a journey that leads to individuation or personal enlightenment. Throughout the process, and in the retelling of the experience, the protagonist fulfils one or more archetypes (Woodside and Megehee, 2010).

\section{Pathways to involvement}

\subsection{Creating awareness and legitimacy}

The first awareness-building component of the Pilgrimage was a fund-raising event to underwrite the Pilgrimage project. An event was staged in Westminster, London, to announce the Pilgrimage project to the media, to establish a sponsorship base and to create awareness. The Pilgrimage was launched and legitimised when Britain's Prince Charles, Patron and Chairman of the Pilgrimage Committee, spoke of the importance of a sense of the sacred in the millennial year which was the reason he became Patron of the project.

Event, e-mail and online communications provided details of a menu of sponsorship offerings: lead donor; principal donor; 'Endow a Cantata'; corporate sponsor; charitable foundations and public funds; supporters. All performances were to live audiences and staged so as to create a profound (visual, auditory, architectural) experience.

After the official launch, awareness and interest in the Pilgrimage was maintained by reviews in the press and music magazines of live performances and recordings as each was released. The packaging of CD releases provided high-involvement and a supporter discount. Each disc includes an introduction by JEG, performance photos, information about the pilgrimage churches in which performances occur, commentary about each cantata, biographies, translation into German and sometimes a personal commentary by pilgrim/performers with their own photographs that document their paths along the Pilgrimage route. A DVD was released that includes a Pilgrimage documentary and an entire Pilgrimage concert at St David's Cathedral, Pembrokeshire, Wales. 
Figure 1 The Bach pilgrimage virtual communications recipe

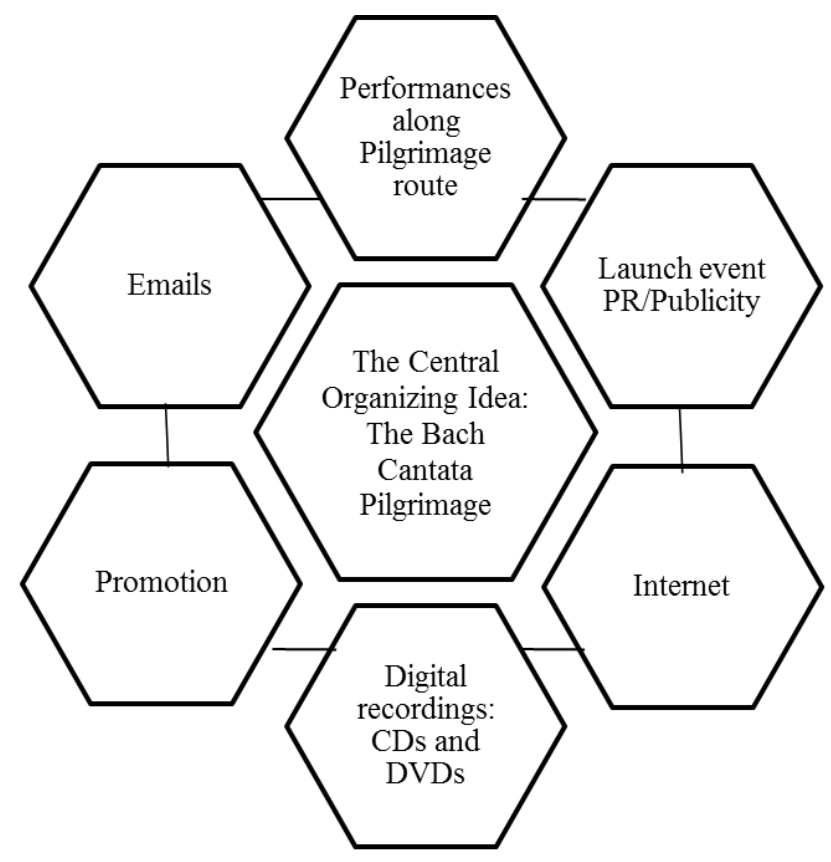

\subsection{Maintaining involvement in the pilgrimage experience}

Pilgrimage management sustained involvement with participants/pilgrims. Pilgrim relationships were developed and maintained by an experiential strategy of engagement. Database communication built on the need for more than customer retention, relationships and personal interaction (Eagle et al., 1999). Transactional and relational database techniques were employed to communicate an experiential dimension to virtual pilgrims. Insightful e-mails were sent to engage participants in the personal events of Pilgrimage performers and of dramatic events (discontinuities, illness, death) that occur during the progress of the Pilgrimage.

Pictorial e-mails were sent to virtual pilgrims and provide an informed announcement that a new volume of JSB Cantatas is about to be released: recording locations on the Pilgrimage route and the cantatas. For example:

"The Seventeenth and Eighteenth Sundays after Trinity ... was the second time the group performed in Leipzig during the Pilgrimage and on this occasion ... the choir sang around Bach's grave behind the altar - one of the most emotional moments of the whole pilgrimage." (Gardiner, 2010)

Engagement is maintained thereby in an authentic way, and in a way that links directly with Pilgrimage sites.

A preview of what was to come also was provided, and such previews build anticipation and a further sense of engagement with the Pilgrimage. "In November we shall release one of the most eagerly requested volumes of the Bach Cantatas series, Volume 13 recorded in Köln and Lüneburg and containing Advent cantatas, some real gems!" 
Figure 1 provides a synoptic of how the various Pilgrimage activities worked together to engage pilgrims and virtual pilgrims in the Pilgrimage experience, especially the performances at churches and among live audiences along the Pilgrimage route. Each activity serves to embed the Pilgrimage in the minds of pilgrims and virtual pilgrims. PR activities build to encourage funding and broader support. PR extends to the internet and to other digital technologies. These tools communicate the essential qualities of the Pilgrimage and the pilgrims' experiences. Promotional incentives are offered to supporter/pilgrims in the form of discounted recordings and personalised e-mail communications. This integrated marketing communication campaign keeps virtual pilgrims fully engaged in the Pilgrimage experience.

\subsection{Cognitive and emotional preparedness}

A pilgrimage requires preparation, the physical act of travel, anticipation, inspiration, and then storytelling to share the experiences. Following Digance (2006) and Hyde and Harman (2011), the Pilgrimage is inspired by a sacred dimension. The journey involves a spiritual experience among the pilgrims and enables a high level of social, personal and spiritual engagement. The Pilgrimage involves travel and deep involvement with specific physical and vital sites that embody the cultural or personal values of each pilgrim.

While the Pilgrimage is neither initiated nor sanctioned by an established religious faith, church, order or denomination, participation sustains a sacred religious context and pilgrimage process (Sharpley and Jepson, 2011; Tribe et al., 2012) in which the Pilgrimage is enacted. JEG and other pilgrims describe the scope of the Pilgrimage as follows:

"Now this tour or this odyssey, or we call it a pilgrimage because it goes to places of worship and places of real spiritual significance, encompasses foremost the places where Bach lived and worked." (JEG)

"We are sixteen different nationalities in the orchestra alone ... and all those sixteen nationalities have come together to make this pilgrimage for the sake of the music of Bach." (Kati Debretseni, Violin)

"Well, I suppose for some people, the experience of doing it in this way ... would be rather like a religious experience. And for me, the closest I get to religion is doing this kind of music." (Susan Flowers, Soprano)

The voluntaristic nature of the Pilgrimage is suggested by this comment from a performer/pilgrim:

"God puts on his best show with Bach and I don't think there is an alternative inspiration other than Christianity that really triggers the music properly ... It's a shame I don't believe it quite myself." (Matthew Truscott, Violin)

The tourism literature considers the issue of sincerity vis à vis appeals to authenticity (MacWilliams, 2002; Schultz, 2003b; Shank and Abelson, 1995; Sichtmann, 2007). Concerns about inauthentic or staged authenticity are also voiced (Sharpley and Jepson, 2011). Analysis of Pilgrims' involvement levels indicates a sense of genuine and sincere commitment:

"I am sure there will be some people saying, you know, "Get off it, what are you trying to do? This isn't a pilgrimage, this is hubris ..."I don't feel that's the case. I am certainly quite clear in my mind that the musicians who've 


\begin{abstract}
accompanied me on this pilgrimage are absolutely genuine and sincere and totally single-minded in their wish to explore, and then to transmit to listening audiences in totally different churches and communities in different parts of Europe, their own love and discovery and sense of re-discovery of this extraordinary music." (JEG, Kirkwall)
\end{abstract}

For JEG authenticity is the alignment of pilgrimage activities to objectives and core values. The Pilgrimage does not attempt a 'museum-like' [Wang, (1999), p.3] approach to Bach, but rather acknowledges that it is impossible today to recreate the original sound of 18th-century boys' voices. A key component of the Pilgrimage is the activity's powerful sacred dimension.

\title{
4.4 The journey and conclusion
}

\subsubsection{The sacrality of nature}

Eliade (1969) develops the concept of the sacrality of nature whereby a sense of the sacred is revealed through the structure of nature. Structures can include the transcendence of the sky, the fecundity of the earth, the cycles of sun and moon, life and death and the solubility and creativity of water (Paden, 2005). Pilgrims' narratives elaborate on a centred and organic focus of the Pilgrimage:

\begin{abstract}
"Bach's cantatas pattern and follow the shape of the liturgical year and the natural cycle of the seasons, and that's something we've lost in so many ways. Bach's music brings you very much back to that organic and centred focus." (JEG, Eisenach)

"Here we are, very early December, approaching the Winter Solstice, the darkest time of the year ... celebrated in music, with just a flicker of light; the hope of the grain in the soil, the winter corn already planted, and the hope that with the turning year, that Spring will return, and that the fruition will follow this." (JEG, Lüneburg)
\end{abstract}

\subsubsection{A sacred and experiential dimension}

The sacred and spiritual dimension of pilgrimage is well documented (Eliade, 1969; Turner and Turner, 1978). Evident in participants' personal expressions is a sense of the experiential: a possible outcome of a mind-and-sense focus and of multi-sensory communications (Nowak and Phelps, 1994). JEG talks about some of the spiritual and experiential aspects of the Pilgrimage:

\begin{abstract}
"One of the spiritual high-points of the pilgrimage was Iona ... a concert quite unlike any other I have ever participated in, because it became a very intimate, and I think, personal experience ... there with the music: Bach's meditation in many ways on the same theme. And the intimacy of the music was reflected in the intimacy of the building and the architecture and the incredible age of the place ... there we were, fifteen-hundred years later with the music of Bach which seemed to sit within those four walls so perfectly." (JEG, Iona)
\end{abstract}

"We have come to believe in something that is certainly beyond our comprehension and something that is beyond our capacity as individuals to understand. And that comes as a direct result of Bach's music. Bach in a way inspires you to a state of religious awareness, and hopefully to a state of grace." (JEG, New York City) 


\subsection{Post-journey storytelling and re-interpretation}

\subsubsection{Individuation and the motivation to participate: a story emerges}

A pilgrimage takes place for reasons that include contemplation, creative thinking and possibly to attain greater unity of thought and action (Vukonic, 1996). Pilgrims may experience the socio-psychological need to reinforce their identities (Crompton, 1979; Hyde and Harman, 2011). This paper takes an interpretive approach to analysis (Weber, 1978) based on etic interpretations of pilgrims' emic interpretations of the significance of the Pilgrimage for their lives; their stories of events. The interpretation of the Pilgrimage's relevance for pilgrims discloses essential structures and meanings, incorporates religious symbolism, and a sense of sacred time, space, and history (Eliade, 1963a, 1963b).

"Yes, we've all become pilgrims even if you weren't sure what it was going to be, to be a pilgrim. But as the great Buddha said, "You cannot know the journey until you are the journey itself"." (Nicholas Robertson, Tenor)

Consideration of individuation theory (Jung, 1940, 1968) provides insights into how people make sense of their responses to cultural experiences.

"I'm Belgian so I had a Catholic background, but then I started to ... find out that every religion had the same beginning, and it's a personal process. And that's what I also find in the music of Bach." (Marcel Buceele, Oboe)

"If you are living with a composer of the stature of Bach on a daily basis for a whole year ... you can't help being affected by it and being touched really to the depths of your being ... I've found that the whole experience this year has been so intense and has got so much under my skin and into the centre of me; I've found that my responses to other people and to situations has changed and also the priorities in my life have changed." (JEG, New York City)

"It was an incredible spiritual journey and I think we are different people now than we were a year ago." (Kati Debretzini, Violin)

"When people kept saying to us during the year, "Have you had enough Bach yet"? I answer, "No". And in fact I wouldn't mind just carrying on doing Bach next week and the week after"." (Katharine Fuge, soprano)

“... We've taken as our motto this year Bach's own belief that where there is music that's performed and approached in a devotional spirit, there is God's grace available. That's hard to define but I think it's the core of what's happened this year ... It really has transformed the way many of us feel about our tasks, our profession, our obligations, our responsibilities as musicians, and our ambitions in the future." (JEG, New York City)

Figure 2 provides a typology of responses to the Pilgrimage. According to the typology a spiritual dimension to the secular pilgrimage exists as well as to the religiously inspired pilgrimage. Each inspiration manifests a sense of obligation which may stifle a potentially spiritual experience. A voluntaristic response offers more fertile ground to evoke a spiritual sense. 
Figure 2 A typology of pilgrimage tourism responses

\section{Sacred/Spiritual}

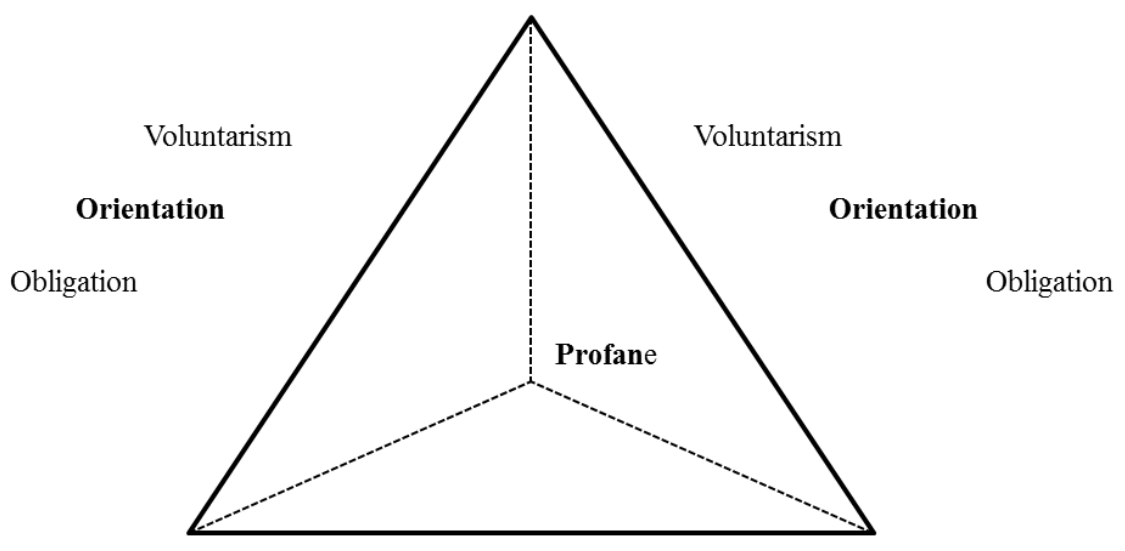

Religious

Secular

The typology reflects the potentially strong currents of religious thought and practice that remain in place in secular society (Schwartz, 2006) and which possibly extends to expressions of re-enchantment (Partridge, 2006). Re-enchantment includes new variations of the sacred journey, a form of manifestly personal volition, and which also may be a response to the powerful influence of archetypes, of deeply held myths that continue to be relevant, and of the journey towards individuation.

The typology represents also the proposition made in this study that, while secular pilgrimage may lack religious motivation and legitimation, a sacred dimension exists. A secular orientation need not imply an orientation towards the profane. This paper argues for breaking the paradigm that attempts to force a fit between the religious and secular, and the sacred and profane dichotomies.

\subsection{Pilgrimage as an archetypal journey}

VNA revises and deepens understanding of the meaning of events in the pilgrim's story and what the story implies about the relationship between the pilgrim and the Pilgrimage (Megehee and Woodside, 2010). The Pilgrimage provides a symbolic context in which a life drama unfolds. Figure 3 provides a visual representation of the Pilgrimage as the archetypal journey and as an individuation process. Building on the pilgrims' own emic descriptions of her thoughts, feelings and experiences, Figure 3 demonstrates how these descriptions can be story-based (Shank, 1999). The individual passes through four stages in order to address the question, "Who am I?" This study incorporates PDT of an epiphany travel template (Woodside and Megehee, 2009) to interpret the Pilgrimage's four stages of the pilgrim's cognitive and emotional preparedness. 
Figure 3 Storyboard of the archetypal journey transforming into the Bach pilgrimage and pilgrim tourist individuation

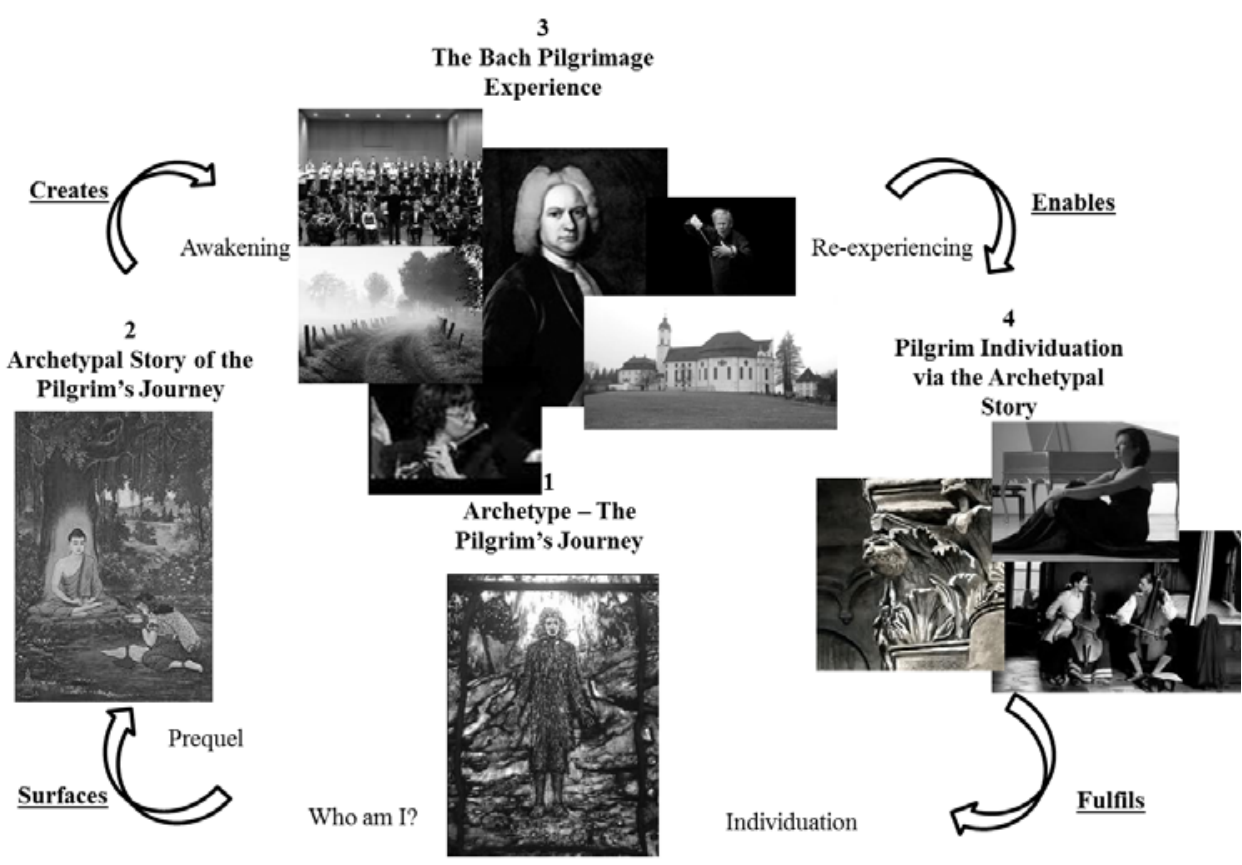

1 Stage One: A prequel and awakening which involves the pilgrim in the archetypal story. In this phase, the pilgrim experiences an unconscious, preconscious, or semiconscious entreaty to satisfy a need, or to fill a space in life. The archetype's power is felt, but is not fully cognised.

2 Phase Two: In which the archetypal need surfaces in the form of a story. The story documents a pilgrim's journey in search for enlightenment. An event or a change may have a significant awakening effect, and become the catalyst for change. In the case of the Pilgrimage, the event occurred during the millennial year, the 250th anniversary of the death of JSB, and the announcement of the Pilgrimage. The Pilgrimage takes on a sacred dimension. The Pilgrimage experience represents an engagement in the story through the journey, searching for a gifted individual who provides insight and meaning. The journey has begun and becomes the pathway to identity, meaning or self-realisation (Digance, 2006; Hyde and Harman, 2011).

3 Phase Three: A cathartic involvement in the pilgrimage process and experience; a deep involvement in the sacred, spiritual and experiential dimensions of Pilgrimage. Activities challenge previous assumptions about the self in relation to the world. The Bach Pilgrimage experience profoundly affects the self-concept of pilgrims.

4 Phase Four: In which pilgrims' individuation is enabled through the Pilgrimage experience. Pilgrims engage in post-journey storytelling and reinterpretation. The pilgrim makes sense (Weick, 1988) of the experience and through re-enactment and story-telling accommodates a new self-concept within a new reality construction (Berger and Luckmann, 1966). 


\section{Conclusions}

The present study addresses four research objectives: firstly, to identify the intentions and other characteristics of the communications; secondly, to explore the psychological state of pilgrims; thirdly, to reveal the focus of individual and group attention; and fourthly, to explore the relevance of archetypes for identifying the motivation to participate in a pilgrimage.

In addressing these objectives, the study advances the theory of pilgrimage tourism and documents how a pilgrim tourist plans, implements, and interprets a spiritual-secular pilgrimage. Results contribute to theory by showing that a secular pilgrimage may have a sacred and spiritual dimension for pilgrims and virtual pilgrims. Furthermore, the alignment of the religious/secular with the sacred/profane dimensions is a forced and contradictory fit. Sacred and profane are viewable here as more akin to the participant's value orientation than to the institutional nature of the pilgrimage.

Analysis of the case of the Pilgrimage, using emic and etic interpretation, indicates that the secular pilgrimage experience can have a sacred dimension, provided the activities aligned with participants' core values. Such a journey can be considered a pathway to identity, meaning, self-realisation and spiritual growth. For some participants, the Pilgrimage is a pathway to a spiritual experience.

Pilgrimage sites are of more than geological interest alone. Participants' experiences of JSB's music at sacred church sites provide a sacred and sensory experience of an intrinsic essence (Lau, 2011). This study proposes the Bach Pilgrimage as a hybrid (secular-sacred) pilgrimage type. The Pilgrimage has a sacred inspiration (the Sacred Cantatas of JSB and the need to ensure an element of the sacred is recognised during the millennial year). The Pilgrimage seeks to engage pilgrims voluntarily and to perform the cantatas solely in religious sites, but as concerts and not as components of a religious service.

Like the religious pilgrimage, the Pilgrimage is devotional (Turner and Turner, 1978) in the sense that participation is made because of a sense of devotion to the life and musical contribution of JSB. The Pilgrimage may share with the secular pilgrimage a sense of being a rite de passage or pathway to identity, meaning or self-realisation (Digance, 2006; Hyde and Harman, 2011) for the pilgrims. In this respect, the Pilgrimage serves as an expression of the archetypal journey. The journey satisfies the powerful need for identification, by the pilgrim, with the totality of the personality; with the self: what Jung (1940) described as the process of individuation.

Through the relationship between sacred pilgrimage sites and creativity the Pilgrimage becomes a journey through time and space. JSB's music, as a work of art, becomes something supra-personal which has "soared beyond the personal concerns of its creator" [Jung, (1966), p.71]. The pilgrim thereby has opportunities for involvement in creative processes.

Digital communications are an acknowledged influence on travellers' intentions and practices (Hahn, 1973; Padanyi and Gainer, 2004). Digital communications extend the Pilgrimage experience in an engaging way. A contribution of this study has been, through enactment, actual and virtual (Guttentag, 2010), to intensify a pilgrimage experience for the long term and to provide an incentive and information for making a Bach Pilgrimage with travel to land-based, geological destinations.

The analysis of Pilgrimage communications suggest some opportunities for further study of varieties of involvement with pilgrimage participation in and visits to Pilgrimage 
sites, which has now become a tourism offering (Randall, 2012). The analysis documents a symbolic context in which a pilgrimage drama unfolds. What is missing in the literature and which would present a considerable research challenge is to explore the sensory experience on pilgrims' and virtual pilgrims' tourism experience - what has been termed the multi-sensory experience (Nowak and Phelps, 1994). Such a multi-sensory experience involves auditory processing, visualising (Pan and Ryan, 2009), and architectonic effect measurement (Wölfflin and Hottinger, 1950) of a tourist's experiences of the pilgrimage through mind, sense, multi-sensory communications and enabled possibly in great part by digital technology (Hulten, 2011).

\section{References}

Alderman, D.H. (2002) 'Writing on the Graceland wall: on the importance of authorship in pilgrimage landscapes', Tourism Recreation Research, Vol. 27, No. 2, pp.27-33.

Aslet, C. (2012) War Memorial, Viking, London.

Badone, E. and Roseman, S.R. (2004) 'Approaches to the anthopology of pilgrimage and tourism', in Badone, E. and Roseman, S.R. (Eds.): Intersecting Journeys: The Anthropology of Pilgrimage and Tourism, pp.1-23, University of Illinois Press, Urbana and Chicago.

Belk, R.W., Wallendorf, M. and Sherry, J.F. (1989) 'The sacred and the profane in consumer behavior: theodicy on the odyssey', Journal of Consumer Research, Vol. 16, No. 1, pp.1-38.

Bellah, R.N. (1964) 'Religious evolution', American Sociological Review, Vol. 29, No. 3, pp.358-374.

Bellah, R.N. (1980) Varieties of Civil Religion, Harper \& Row, New York.

Benedict, R. (1946) The Chrysanthemum and the Sword: Patterns of Japanese Culture, Charles E. Tuttle, Tokyo.

Berger, P.L. (1967) The Sacred Canopy: Elements of a Sociological Theory of Religion, Doubleday, Garden City.

Berger, P.L. and Luckmann, T. (1966) The Social Construction of Reality, Doubleday, New York.

Bridger, D., Wolk, S. and Eban, A. (1976) The New Jewish Encyclopedia, Behrman House, West Orange: NJ.

Cohen, E. (1991) 'Pilgrimage and tourism: convergence and divergence', in Morinis, E.A. (Ed.): Journeys to Sacred Places, Greenwood Press, Wrestport, CT.

Cohen, E. (1992) 'Pilgrimage centres: concentric and excentric', Annals of Tourism Research, Vol. 19, No. 1, pp.33-50.

Collins-Kreiner, N. (2010) 'Researching pilgrimage: continuity and transformation', Annals of Tourism Research, Vol. 37, No. 2, pp.440-456.

Crompton, J.L. (1979) 'Motivations for pleasure vacation', Annals of Tourism Research, Vol. 6, No. 4, pp.408-424.

Dahlberg, A. (1991) The Body as a Principle of Holism: Three Pilgrimages to Lourdes, University of Illinois Press, Urbana and Chicago.

Digance, J. (2006) 'Religious and secular pilgrimage: journeys redolent with meaning', in Timothy, D.J. and Olsen, D.H. (Eds.): Tourism, Religion and Spiritual Journeys, pp.36-48, Routledge, London.

Douglas, M. (1966) Purity and Danger, Routledge, London.

Durkheim, E. (2008) The Elementary Forms of Religious Life, in C. Cosman (Trans.), Oxford University Press, New York.

Durkheim, E. and Mauss, M. (1967) Primitive Classification, University Of Chicago Press, Chicago. 
Eade, J. (1992) 'Pilgrimage and tourism at Lourdes, France', Annals of Tourism Research, Vol. 19, No. 1, pp.18-32.

Eade, J. and Sallnow, M.J. (Eds.) (2000) Contesting the Sacred: The Anthropology of Christian Pilgrimage, University of Illinois Press, Urbana and Chicago.

Eagle, L., Kitchen, P.J., Hyde, K., Fourie, W. and Padisetti, M. (1999) 'Perceptions of integrated marketing communications among marketers and ad agency executives in New Zealand', International Journal of Advertising, Vol. 18, No. 1, pp.89-119.

Eliade, M. (1959) The Sacred and the Profane: The Nature of Religion, in W.R. Trask (Trans.), Harcourt, Brace, New York.

Eliade, M. (1963a) Patterns in Comparative Religion, in R. Sheed (Trans.), World, New York.

Eliade, M. (1963b) The Quest: History and Meaning in Religion, University of Chicago Press, Chicago.

Eliade, M. (1969) Images and Symbols, Sheed and Ward, New York.

Eliade, M. (1996) Patterns in Comparative Religion, University of Nebraska Press, Omaha.

Gardiner, I. (2010) Bach Pilgrimage, Monteverdi Choir and Orchestra, London.

Gardiner, J.E. (2011) Soli Deo Gloria, Vol. 2012, Monteverdi Choir and Orchestra, London.

Geertz, C. (1973) 'Religion as a cultural system', in Geertz, C. (Ed.): Approaches to the Study of Religion, Basic Books, New York.

Gellner, E. (1974) Legitimation of Belief, Cambridge University Press, Cambridge.

Green, M.C. and Brock, T.C. (2000) 'The role of transportation in the persuasiveness of public narratives', Journal of Personality and Social Psychology, Vol. 79, No. 5, pp.701-721.

Guttentag, D.A. (2010) 'Virtual reality: applications and implications for tourism', Tourism Management, Vol. 31, No. 5, pp.637-651.

Hahn, R.A. (1973) 'Understanding beliefs: an essay in the methodology of the statement and analysis of belief systems', Current Anthropology, Vol. 14, No. 3, pp.207-231.

Hofstede, G. (2003) Culture's Consequences: International Differences in Work-Related Values, 2nd ed., Sage Publications, Beverly Hills, CA.

Houtsma, M.T., Wensinck, A.J. and Arnold, T.W. (1993) E.J. Brill's First Encyclopaedia of Islam, pp.1913-1936, Brill, Boston.

Hulten, B. (2011) 'Sensory marketing: the multi-sensory brand-experience', European Business Review, Vol. 23, No. 3, pp.256-273.

Hunt, S.D. and Menon, A. (1995) 'Metaphors and competitive advantage: evaluating the use of metaphors in theories of competitive strategy', Journal of Business Research, Vol. 33, No. 2, pp.81-90.

Hyde, K.F. and Harman, S. (2011) 'Motives for a secular pilgrimage to the Gallipoli battlefields', Tourism Management, Vol. 32, No. 6, pp.1343-1351.

Jung, C.G. (1940) Integration of Personality, in S.M. Dell (Trans.), Kegan Paul, Trench Trubner, London.

Jung, C.G. (1966) The Spirit in Man, Art, and Literature, in R.F.C. Hull (Trans.), Princeton University Press, Princeton, NJ.

Jung, C.G. (1968) Analytical Psychology: Its Theory and Practice, Routledge \& Kegan Paul, London and Henley.

Jung, C.G. (1969) 'The archetypes and the collective unconscious', In Read, H., Fordham, M. and Adler, G. (Eds.): Collective Works, Vol. 9, Princeton University Press, Princeton, NJ.

Lau, R.W.K. (2011) 'Tourist sights as semiotic signs: a critical commentary', Annals of Tourism Research, Vol. 38, No. 2, pp.711-714.

MacWilliams, M. (2002) 'Virtual pilgrimages on the internet', Religion, Vol. 32, No. 4, pp.315-335.

Martin, D. (1978) A General Theory of Secularization, Blackwell, London. 
McKercher, B. and du Cros, H. (2002) Cultural Tourism: The Partnership Between Tourism and Cultural Heritage Management, Haworth Press, Binghamton, NY.

Megehee, C.M. and Woodside, A.G. (2010) 'Creating visual narrative art for decoding stories that consumers and brands tell', Psychology and Marketing, Vol. 27, No. 6, pp.603-622.

Nowak, G. and Phelps, J. (1994) 'Conceptualizing the integrated marketing communications phenomenon: an examination of its impact on advertising practices and its implications for advertising research', Journal of Current Issues and Research in Advertising, Vol. 16, No. 1, pp.49-66.

Olsen, D.H. (2010) 'Pilgrims, tourists and Max Weber's 'ideal types', Annals of Tourism Research, Vol. 37, No. 3, pp.848-851.

Padanyi, P. and Gainer, B. (2004) 'Marketing orientation on the non-profic sector: taking multiple constituencies into consideration', Journal of Marketing Theory and Practice, Vol. 12, No. 2 , pp.43-58.

Paden, W.E. (2005) 'Comparative religion', in R.J. Hinnells (Ed.): The Routledge Companion to the Study of Religion, pp.208-225, Routledge, London.

Pan, S. and Ryan, C. (2009) 'Tourism sense making: the role of the senses and travel journalism', Journal of Travel and Tourism Marketing, Vol. 26, No. 7, pp.625-639.

Partridge, C.H. (2006) 'The re-enchantment of the west: alternative spiritualities, sacralization, popular culture and occulture', T.\& T.Clark Ltd., London.

Pearsall, D. (1983) 'Chaucer's pardoner: the death of a salesman', The Chaucer Review, Vol. 17, No. 4, pp.358-365.

Princeton University Cognitive Science Lab. (2005) WordNet Online Lexical Database, Princeton University, Princeton, N.J.

Randall, M. (2012) The Johann Sebastian Bach Journey, Martin Randall Travel, London.

Reader, I. and Walter, T. (Eds.) (1992) Pilgrimage in Popular Culture, Palgrave Macmillan, Basingstoke, UK.

Schultz, D.E. (2003a) 'Evolving marketing and marketing communication into the twenty-first century', in Iacobucci, D. and Calder, B. (Eds.): Kellogg on Integrated Marketing, Wiley, New Jersey.

Schultz, D.E. (2003b) 'The next generation of integrated marketing communication', Interactive Marketing, Vol. 4, No. 4, pp.318-319.

Schwartz, S.H. (2006) 'A theory of cultural value orientations: explication and applications', Comparative Sociology, Vol. 5, Nos. 2-3, pp.137-182.

Scruton, R. (2014) The Soul of the World, Princeton University Press, Princeton, NJ.

Shank, R.C. (1999) Dynamic Memory Revisited, Cambridge University Press, Cambridge.

Shank, R.C. and Abelson, R.P. (1995) 'Knowledge and memory: the real story', in Wyer, R.S. (Ed.): Knowledge and Memory: The Real Story, Lawrence Erlbaum Associates, Inc., Hillsdale, NJ.

Sharpley, R. and Jepson, D. (2011) 'Rural tourism: a spiritual experience?', Annals of Tourism Research, Vol. 38, No. 1, pp.52-71.

Sichtmann, C. (2007) 'An analysis of the antecedents and consequences of trust in a corporate brand', European Journal of Marketing, Vol. 41, Nos. 9/10, pp.999-1015.

Smith, V.L. (1992) 'The quest in guest', Annals of Tourism Research, Vol. 19, No. 1, pp.1-17.

Stone, P.J., Dunphy, D.C., Smith, M.S. and Ogilvie, D.M. (1966) The General Inquirer: A Computer Approach to Content Analysis, MIT Press, Cambridge, MA.

Tribe, J., Xiao, H. and Chambers, D. (2012) 'The reflexive journal: inside the black box', Annals of Tourism Research, Vol. 39, No. 1, pp.7-35.

Turner, V. and Turner, E. (1978) Image and Pilgrimage in Christian Culture: Anthropological Perspective, Blackwell, Oxford.

Vukonic, B. (1996) Tourism and Religion, Pergamon, Oxford. 
Wang, N. (1999) 'Rethinking authenticity in tourism experience', Annals of Tourism Research, Vol. 26, No. 2, pp.349-370.

Weber, M. (1930) The Protestant Ethic and the Spirit of Capitalism, George Allen \& Unwin, London.

Weber, M. (1964) The Sociology of Religion, in E. Fischoff (Trans.), Beacon Press, Boston.

Weber, M. (1978) Economy and Society, Reissue ed., University of California Press, Berkeley.

Weber, R.P. (1990) Basic Content Analysis, 2nd ed., Sage, Newbury Park, CA.

Weick, K.E. (1988) 'Enacted sense-making in crisis situations', Journal of Management Studies, Vol. 25, No. 4, pp.305-317.

Weick, K.E., Sutcliffe, K.M. and Obstfeld, D. (2005) 'Organizing and the process of sense-making', Organization Science, Vol. 16, No. 4, pp.409-421.

Wilson, B.R. (1966) Religion in Secular Society: A Sociological Comment, Watts, London.

Wilson, B.R. (1999) New Religious Movements: Challenge and Response, Routledge, London.

Wölfflin, H. and Hottinger, M.D.M. (1950) Principles of Art History: The Problem of the Development of Style in Later Art, Dover, Mineola, NY.

Woodside, A.G. (2008) 'Using the forced metaphor-elicitation technique (FMET) to meet animal companions within self', Journal of Business Research, Vol. 61, No. 5, pp.480-487.

Woodside, A.G. and Megehee, C.M. (2009) 'Travel storytelling theory and practice', Anatolia, Vol. 20, No. 1, pp.86-99.

Yang, C.K. (1961) Religion in Chinese Society: A Study of Contemporary Social Functions of Religion and Some of Their Historical Factors, Waveland Press, Prospect Heights, IL.

Yearley, S. (1992) 'Green ambivalence about science: legal-rational authority and the scientific legitimation of a social movement', The British Journal of Sociology, Vol. 43, No. 4, pp.511-532. 